\title{
APPLICATION OF BASALTIC COMPOSITIONS FOR THE PRODUCTION OF BIOCIDAL PAPER
}

\author{
V.M. Shevchenko, N.A. Guts, A.Ye. Shpak \\ National Technical University of Ukraine "KPI named Igor Sikorsky", \\ 03056, Kyiv, Peremogyav., 37, (+38044)236-97-74, e-mail: gutsanelya@ukr.net
}

One of the main problems today is the storage of funds, provision of storage conditions, the absence of mold, microbiological dispersions in the air, processing of documents, detoxification of previously processed materials.

In this work, samples of papers (condenser, writing, carton for lamination) and usage of biocidal materials (Polydez, Gembar and Metatin) were investigated. The technology of processing samples is not very simple. Biocidal effects were carried out on test cultures of microscopic fungi taken from damaged documents.

In addition, samples of papers processed with composite mixtures containing basalt and cellulose fibers, montmorillonite clay and sodium resin salts (SSRA) or sodium humate (SH) were studied in parallel. Aging of samples was monitored by indicators such as the material's whiteness and breakthrough strength (n.d.f.) - the properties that are sensitive to the aging process.

It has been proved that samples containing basalt and cellulose fibers, montmorillonite and sodium salts of resin acids (or sodium humate) are more likely to suppress the spread of fungi and microorganisms than official state biocidal materials.

Therefore, in this work it is proposed the material and composition mixture, which guarantees certain physical and mechanical properties of the finished product and has a much simpler and cheaper technology to obtain the disinfecting material.

Keywords: biostable material, cellulose, basalt fibers, clay minerals.

\section{Introduction}

Despite of the development of computer (paperless) technologies, paper carrier of information is still the most widespread, widely used, continuously needed [1]. These are textbooks, notebooks, newspapers, geographic maps, wallpapers, breads, money, documents, drawings, etc. One can conclude that paper is a priceless spiritual bread of mankind. How to save it?

It is known that the paper made of vegetable fibers, aging with time, and this process is irreversible (the chemical composition of the paper changes, mechanical strength changes, brittleness appears, yellowish appears [2]), although it is known that from fiber of the tubular structure and tape structure it is possible to get a durable paper with a closed surface; and a little grinded fibers give the opportunity to get the most durable paper, and so on.

However, the problem of keeping funds is one of the main in this direction. It means ensuring storage conditions, the absence of mold and microbiological dispersions in the air, processing documents and detoxifying previously treated materials. In addition, in parallel, there is a problem of fighting the smell of mold, appearing of fragility of pages and "black" mold.

One of the ways to combat this phenomenon is to use biocidal materials and treat them with investigated samples of paper to obtain biocidal paper. 
In general, the concept of "biocidal" paper includes different types of paper. So, a paper that has the ability to kill (destroy) a bacterium - a bactericidal paper, a paper that has the ability to destroy moldy fungi - fungicidal, and destroy insects, beetles, etc. - insecticidal. Each of the biocidal types of paper may have the ability to destroy one or two or even three of the specified types.

One of the main purposes of this type of paper is the packaging of various types of foods intended for extended shelf life (butter, cheese, meat, fish, fruits, vegetables, etc.).

Interesting is the manufacturing of paper bags with biocidal properties. In such bags you can store flour, cereals, sugar, etc. without damaging them with rodents, beetles and other pests.

Biocidal compounds used to create bioprotective paper are very different. Recently, different types of biocides are used [1]. A prerequisite for biocidal use is not a very complicated technology which provides safety for the health of storage personnel and users [3].

In work [4] found "tastes" (pests) of books. All three types of scarabs (blanket, anthrenus and ham) very like cotton and sulphate paper products.

There are good results of the disinfection of books when they were treated with vacuum in autoclaves with formaldehyde at $\mathrm{t}=30-40$ degrees Celsius and / or in the electric high-frequency field [5, 6], ozone processing [7].

It is known about the use of formalin, ammonia, furatsilina, tiomula, DDT, and many others, but none of them solved the problem completely.

\section{Experimental part}

For fungicidal and per-page paper treatments, biocidal preparations Methatein GT and derivatives of polyhexamethylene guanadine (PGMG): Gembar and Polyhedes were used. All of them belong to low hazard substances (Grade 4 hazard).

The study of biocidal activity was carried out on 11 test cultures of microscopic fungi taken from damaged library documents: Alternaria alternata; Aspergillus niger, Aspergillus repens, Aspergillus ustus, Aspergillus versicolor, Chaetomium globosum, Cladosporium sphaerospermum, Paecilomyces variotii, Penicillium aurantiogriseum, Penicillum tardum, Trichoderma viride. All these types of fungi are destructors of various materials.

All work related to the preparation and usage of biocidal solutions was carried out with the observance of personal security measures that protect the respiratory system, skin, eyes, etc.

The processing of documents with biocidal solutions was carried out very carefully (processed documents were re-lay by biocidal papers, put in stacks to prevent deformation, dried by hair dryer). The worker was wearing special clothing, hygienic masks, rubber gloves and so on.

All surface of the room was carefully cleaned and treated with biocide solution, room was closed for a day and then well ventilated.

$2 \%$ of aqueous solutions of Gembar, Polyester and Methatein GT were studied. Samples of paper were wet on both sides per page with drugs for 4-5 seconds. After drying, the samples of the paper were infected with spore suspensions of fungi test cultures in a solution of mineral salts and sugar (Chapek-Doxa medium) simulating the conditions of mineral and organic contamination of the material. The prepared samples were then spread on a Chapek-Doxa (Petri dish) and kept for 14 days at a temperature of about 29 degrees Celsius, with a relative humidity of $90 \%$.

The evaluation of the fungicidal properties of the test paper samples was carried out in 14, 21 and 28 days.

Aging of paper after treating them with biocides was studied according to such parameters as paper whiteness (10) and breakage strength. Samples of condenser paper, writing paper and carton for lamination were investigated. The humidity measurements were measured as described in [10] by the carl Zeiss leukometer. Breakthrough strength is one of the main indicators of the strength of 
papers, which depend on the length of the fibers from which paper is produced, their strength, durability, elasticity of the forces of communication between the fibers. This method is sensitive to the aging process of paper [2]. Breakthrough strength was measured according to DSTU 3476 [11].

It is simpler and most certainly cheaper to use the inorganic fibers in the compositions for the processing of any papers, such as basalt. These are highly thermostable fibers with low chemical activity, attracting attention because they do not promote the spread of different types of fungi and microorganisms, are not subject to mold, bacteria, various types of pests, insects, beetles, etc. These chemically little active fibers can be used in the composite mixture for materials of this direction.

There are known carton-like materials based on basalt fibers (scales, felt, slabs, etc.), for which it is not necessary to use binding agents because they have evenly interwoven fibers of the basalt fiber itself. In such material the linkage between the fibers is purely mechanical.

Binding substances are used to obtain a thin, durable and flexible paper-like material, most often it is cellulose fibers (if the future usage does not require a temperature above 120-130 Celsius degrees).

Previous studies have proved [8] that basaltic and cellulose fibers in the solution have the same negative by sign and different electrokinetic potential that occurs at the interface of the phases (fiber - solution). By recharging the surface of one of the contacting fibers (for example, basalt fibers with help of aluminum sulfate), we obtain a fiber with an oppositely charged potential (positive).

Now the oppositely charged surfaces of two fibers (basalt and cellulose) will not push out from each other, but be attracted, which positively affects the strength of the finished product and its biostability.

Earlier studies have shown that clay minerals can be used to obtain a solid, thin, elastic, and even heat-resistant material that greatly slows the growth and cultivation of microorganisms [9].

In the work sulphite cellulose of grade A-11, basalt fiber with a diameter of 1.4 microns, clay mineral montmorillonite of Pyzhiv field were used.

It was found that the effect of the studied biocides on fungal cultures can be described as fungicidal. The data is given in Table 1, from which it may be seen that the papers breakthrough strength (the number of double folds, n.d.f.) and the whiteness decreases, losing their initial values.

Samples of papers a) and b) (condenser and writing) acquired fungicidal properties, c) (carton for lamination) did not acquire a fungicidal effect, probably because this material (carton) in comparison to other papers has a higher density and thickness, which does not allow used agents to soak it properly.

In addition, samples of the same papers (condenser, writing and carton for lamination), processed by composition, which included basaltic and cellulose fiber, montmorillonite clay mineral, and sodium salts of resin acids (or sodium humate) were investigated in parallel. Compositional mixture of these samples is given below:

A) $30 \%$ basalt fiber (Bas) $+70 \%$ cellulose fiber $(\mathrm{Cel})+15 \%$ (to the weight of the fibers) montmorillonite clay (MOT) $+10 \%$ (to the weight of the fibers) sodium humate $(\mathrm{SH})$;

B) $50 \%$ basalt fiber (Bas) $+50 \%$ cellulose fiber $(\mathrm{Cel})+15 \%$ (to the weight of the fibers) montmorillonite (MOT) $+10 \%$ (to the composition of the fibers) sodium humate (SH);

Some compositions had a slightly different mixture:

C) $30 \%$ basalt fiber (Bas) $+70 \%$ cellulose fiber $(\mathrm{Cel})+15 \%$ (to the weight of the fibers) montmorillonite $(\mathrm{MOT})+10 \%$ (to the composition of the fibers) sodium salts of resin acids (SSRA); 
D) $50 \%$ basalt fiber (Bas) $+50 \%$ cellulose fiber $(\mathrm{Cel})+15 \%$ (to the weight of the fibers) montmorillonite (MOT) $+10 \%$ (to the composition of the fibers) sodium salts of resin acids (SSRA).

Table 1. Properties of papers before and after processing them by biocides.

\begin{tabular}{|c|c|c|c|c|c|}
\hline \multicolumn{2}{|l|}{ Index } & \multirow{2}{*}{ Before processing } & \multicolumn{3}{|c|}{$\begin{array}{c}\text { After processing by } 20 \% \\
\text { solutions }\end{array}$} \\
\hline \multicolumn{2}{|l|}{ muex } & & M & G & $\mathbf{P}$ \\
\hline Condenser paper. & a) & & & & \\
\hline \multicolumn{2}{|l|}{ Whiteness, \% } & 62,4 & 60,4 & 60,6 & 61,3 \\
\hline \multicolumn{2}{|c|}{ Breakthrough strength (n.d.f.) } & 79,9 & 658 & 722 & 575 \\
\hline Writing paper. & в) & & & & \\
\hline \multicolumn{2}{|l|}{ Whiteness, \% } & 74,8 & 68,6 & 72,4 & 74,3 \\
\hline \multicolumn{2}{|c|}{ Breakthrough strength (n.d.f.) } & 10,6 & 10,3 & 10,7 & 10,4 \\
\hline Carton for lamination. & c) & & & & \\
\hline \multicolumn{2}{|l|}{ Whiteness, \% } & 64,6 & 52,4 & 51,8 & 51,7 \\
\hline \multicolumn{2}{|c|}{ Breakthrough strength (n.d.f.) } & 1324 & 1368 & 1380 & 1394 \\
\hline
\end{tabular}

\section{M - Metatin, G - Gembar, P - Polydez.}

Table 2 summarizes the data of the physical and mechanical properties of the condenser paper, the writing paper, and the carton for lamination, which were processed by the above-mentioned compositional media.

Table 3 summarizes the physical and mechanical properties of condenser paper, writing paper and carton for lamination, which were processed by a mixture of compositions containing basalt and cellulose fibers, montmorillonite clay and sodium salts of resin acids (options c) and d)). 
Table 2.Physical-mechanical properties of papers

\begin{tabular}{|c|c|c|}
\hline Compositive mixture & Whiteness \% & Breakthrough strength (n.d.f.) \\
\hline $\begin{array}{c}\text { a) } 30 \%(\mathrm{Bas})+70 \%(\mathrm{Cel})+15 \% \\
(\mathrm{MOT})+10 \%(\mathrm{SH}) \\
\text { Condenser paper }\end{array}$ & 64,3 & 74,8 \\
\hline $\begin{array}{l}\text { a) } 30 \%(\mathrm{Bas})+70 \%(\mathrm{Cel})+15 \% \\
\text { (MOT) }+10 \%(\mathrm{SH}) \\
\text { Writing paper }\end{array}$ & 68,4 & 78,6 \\
\hline $\begin{array}{c}\text { a) } 30 \%(\mathrm{Bas})+70 \%(\mathrm{Cel})+15 \% \\
(\mathrm{MOT})+10 \%(\mathrm{SH}) \\
\text { Carton }\end{array}$ & 52,8 & 1578,2 \\
\hline $\begin{array}{l}\text { b) } 50 \%(\mathrm{Bas})+50 \%(\mathrm{Cel})+15 \% \\
\text { (MOT) }+10 \%(\mathrm{SH}) \\
\text { Condenser paper }\end{array}$ & 62,4 & 72,2 \\
\hline $\begin{array}{c}\text { b) } 50 \%(\mathrm{Bas})+50 \%(\mathrm{Cel})+15 \% \\
\text { (MOT) }+10 \%(\mathrm{SH}) \\
\text { Writing paper }\end{array}$ & 66,6 & 76,4 \\
\hline $\begin{array}{c}\text { b) } 50 \%(\mathrm{Bas})+50 \%(\mathrm{Cel})+15 \% \\
(\mathrm{MOT})+10 \%(\mathrm{SH}) \\
\text { Carton }\end{array}$ & 52,2 & 1572,4 \\
\hline
\end{tabular}

It was interesting to investigate whether the homo-ion form of montmorillonite, which is part of compositions based on basalt and cellulose fibers, is influenced by biocidal characteristics of materials. It is known [12] that bentonite clay is hydrophilic, has a relatively high specific surface, a considerable volume capacity, can influence and regulate the strong properties of coagulation structures.

The montmorillonite clay from the Pyzhiv field was used in various homo-ion forms of exchangeable metal cations. The means for obtaining a certain homo-ion for montmorillonite is described in [13]. It has been proved that the maximum strengthening of coagulation systems occurs when adding $10 \%$ sodium ions supplements to $15 \%$ clay suspension.

Somewhat worse results are obtained with the use of calcium salts and even worse with the use of aluminum salts. 
Table 3. Physical-mechanical properties of papers

\begin{tabular}{|c|c|c|}
\hline Compositive mixture & Whiteness \% & $\begin{array}{c}\text { Breakthrough strength } \\
\text { (n.d.f.) }\end{array}$ \\
\hline $\begin{array}{c}\text { c) } 30 \%(\mathrm{Bas})+70 \%(\mathrm{Cel})+ \\
15 \%(\mathrm{MOT})+10 \%(\mathrm{SSRA}) \\
\text { Condenser paper }\end{array}$ & 68,4 & 75,2 \\
\hline $\begin{array}{c}\text { c) } 30 \%(\mathrm{Bas})+70 \%(\mathrm{Cel})+ \\
15 \%(\mathrm{MOT})+10 \%(\mathrm{SSRA}) \\
\text { Writing paper }\end{array}$ & 69,2 & 78,4 \\
\hline $\begin{array}{c}\text { c) } 30 \%(\mathrm{Bas})+70 \%(\mathrm{Cel})+ \\
15 \%(\mathrm{MOT})+10 \%(\mathrm{SSRA}) \\
\text { Carton }\end{array}$ & 53,3 & 1582,2 \\
\hline $\begin{array}{c}\text { d) } 50 \%(\mathrm{Bas})+50 \%(\mathrm{Cel})+ \\
15 \%(\mathrm{MOT})+10 \%(\mathrm{SSRA}) \\
\text { Condenser paper }\end{array}$ & 64,4 & 74,2 \\
\hline $\begin{array}{c}\text { d) } 50 \%(\mathrm{Bas})+50 \%(\mathrm{Cel})+ \\
15 \%(\mathrm{MOT})+10 \%(\mathrm{SSRA}) \\
\text { Writing paper }\end{array}$ & 75,2 & 76,8 \\
\hline $\begin{array}{c}\text { d) } 50 \%(\mathrm{Bas})+50 \%(\mathrm{Cel})+ \\
15 \%(\mathrm{MOT})+10 \%(\mathrm{SSRA}) \\
\text { Carton }\end{array}$ & 52,8 & 1584,4 \\
\hline
\end{tabular}

For comparison, the same compositional materials were taken, replacing the original montmorillonite with treated by sodium salts. The data given in Table 4 shows that the transition of natural montmorillonite into sodium form (treated by sodium salts) has a positive effect on the clay mineral, i.e. the use of Na-montmorillonite stimulated the formation of compositions stronger than the previous ones.

Table 4 summarizes the physical and mechanical properties of condenser paper, writing paper, and laminated carton treated by compositions comprising 30\% $(50 \%)$ of basalt fiber (Bas) $+70 \%$ $(50 \%)$ of cellulose fiber $(\mathrm{Cel})+15 \% \mathrm{Na}-$ montmorillonite (MOT) $+10 \%$ (to the weight of fibers) of sodium salt of resin acids (SSRA). 
Table 4. Physical-mechanical properties of papers

\begin{tabular}{|c|c|c|}
\hline Compositive mixture & Whiteness \% & $\begin{array}{l}\text { Breakthrough } \\
\text { strength (n.d.f.) }\end{array}$ \\
\hline $\begin{array}{c}30 \%(\mathrm{Bas})+70 \%(\mathrm{Cel})+15 \% \mathrm{Na}-(\mathrm{MOT})+10 \% \mathrm{H} \\
\quad(\mathrm{SSRA}) ; \\
\text { Condenser paper }\end{array}$ & 70,2 & 78,5 \\
\hline $\begin{array}{c}30 \%(\mathrm{Bas})+70 \%(\mathrm{Cel})+15 \% \mathrm{Na}-(\mathrm{MOT})+10 \% \mathrm{H} \\
(\mathrm{SSRA}) ; \quad \text { Writing paper }\end{array}$ & 70,0 & 79,8 \\
\hline $\begin{array}{c}30 \%(\mathrm{Bas})+70 \%(\mathrm{Cel})+15 \% \mathrm{Na}-(\mathrm{MOT})+10 \% \mathrm{H} \\
(\mathrm{SSRA}) ;\end{array}$ & 58,3 & 1678,4 \\
\hline $\begin{array}{l}50 \%(\mathrm{Bas})+50 \%(\mathrm{Cel})+15 \% \mathrm{Na}-(\mathrm{MOT})+10 \% \\
(\mathrm{SSRA}) ; \\
\text { Condenser paper }\end{array}$ & 68,8 & 77,6 \\
\hline $\begin{array}{lr}50 \%(\mathrm{Bas})+50 \%(\mathrm{Cel})+15 \% \mathrm{Na}-(\mathrm{MOT})+10 \% \\
(\mathrm{SSRA}) ; & \text { Writing paper }\end{array}$ & 78,4 & 79,4 \\
\hline $\begin{array}{cc}50 \%(\mathrm{Bas})+50 \%(\mathrm{Cel})+15 \% \mathrm{Na}-(\mathrm{MOT})+10 \% \\
(\mathrm{SSRA}) ; & \text { Carton }\end{array}$ & 54,6 & 1662,4 \\
\hline
\end{tabular}

Specimens that had in the composition sodium humates instead of sodium salts of resin acids have similar patterns according to the values of whiteness and strength, therefore they are not mentioned in this report.

\section{Conclusions:}

1. Virtually all experimental materials were, to varying degrees, been damaged by various microorganisms and partly by fungi.

2. These studies provide an opportunity to offer material and composition, which effectively inhibit the growth of fungi, mold, reduces the amount of agglomerate spores, increases resistivity.

3. Materials containing in the composition of more cellulosic fibers, are more affected by fungi and faster. The mildew appeared on day 15, and by the end of the test (on day 28), the mold covered the material by about $40 \%$.

4. Biodegradability of materials increases with increasing influence of basalt fiber in composition.

5. The best physico-mechanical properties and biodegradability indices are compositional bases containing basalt and cellulosic fibers, Na- montmorillonite clay and sodium salts of resin acids (or sodium humate) that have been used as biocidal material. Physics - the mechanical characteristics of materials when applied with the use of such biocidal means is much better than in other cases, and the technology of paper processing is simpler, easier and cheaper. 


\title{
References
}

1. Nagi Terry A. Insight from vision 21-st the printing industry redefined for the 21-st century. Solut!. People Process Paper .2002. 10(85): 33.

2. Flyate D. M. Properties of Paper Edition 3. (Moscow, Forestry, 1986).

3. Strassburg Richard. Further Information on the Use of ethylene oxide as a Library and Archival Fumigant. (SAA Leaflet, 1983)

4. Kazumina O.V., Baryshnikova Z.P. Collection "Paper Aging" (Publishing house "Science", 1995)

5. Donskoy A.V. Disinfection and Restoration of Library Materials (Leningrad, Publishing House of the State Public Library, 1989)

6. Zagulyayeva Z.A. Problems of conservation and restoration of paper and parchment. (Publishing house of the Academy of Sciences of the USSR,1982).

7. John H. Halnes, Stuart A. Kohler. An evaluation of ortho-phenol as a fungicidal fumigant for archives and libraries. Y. Amer. Inst. Conserv. 1996. 25(1):49.

8. Shevchenko V.M., Alekseev O.L.Principles of recharging and its influence on the properties of paper-like materials. Abstracts of the conference "Nano-sized systems. 2004. 12:170.

9. Shevchenko V.M., Guts N.A., Pidgornyi A.V. Bentonite clays in compositions with basalt fibers. Collection of scientific works SWorld. 2016. Book 10. 1(42): 80.

10. DSTU 3364-96 Cellulose. Method of determining the whiteness

11. DSTU 3476-96 Paper. Definition of whiteness on fracture during multiple folds

12. Kruglitskyi N.N. Physics-chemical bases of regulating properties of the disperse of clay minerals. (Kyiv: Naukova dumka, 1994).

13. Shevchenko V.M., Guts N.A. Influence of temperature and homeostasity of dispersed minerals on characteristics of composite materials of basalt. Collection of scientific works SWold. 2014. 30: 27.

\section{ЗАСТОСУВАННЯ БАЗАЛЬТОВИХ КОМПОЗИЦЙ ПРИ ОДЕРЖАННІ БІОЦИДНОГО ПАПЕРУ}

\author{
В.М. Шевченко, Н.А. Гуц, А.С. Шиак \\ Національний технічний університет Украӥни «КПІ імені Ігоря Сікорського», \\ 03056,Київ, пр-т Перемоги, 37, \\ (+38044)236-97-74,e-mail: gutsanelya@ukr.net
}

Одна з основних проблем зберігання паперової продукиії сьогодні-изе зберігання фондів, забезпечення умов зберігання, відсутність плісняви, мікробіологічних дисперсій у повітрі, обробка документів, детоксикація оброблених раніше матеріалів.

В роботі досліджували зразки паперів (конденсаторного, писального, картону для ламінування) та застосування біоцидних матеріалів (Полідезу, Гембару та Метатіну). 
Технологія обробки зразків не дуже проста. Дію біоцидних проводили на тест - культурах мікроскопічних грибів, щзо були ізольовані з пошкоджених документів.

Крім того, паралельно досліджувались зразки паперів, щ̧о оброблялись композиційним складом, щзо містить базальтове та иелюлозне волокна, монтморилонітова глина та натрієві солі смоляних кислот (SSRA) або Натрію гумат (SH). Старіння зразків спостерігали за такими показниками, як білість матеріалів та міиність на злам, (ч.n.n.) властивості, щзо чутливі до процесу старіння.

В роботі доведено, щзо зразки, щзо мають у композиційному складі базальтове та целюлозне волокна, монтморилоніт та натрієві солі смоляних кислот (або Натрію гумат) у більшій ступені пригнічують розповсюдження грибів та мікроорганізмів, ніж офіційні державні біоцидні матеріали.

Тому в роботі пропонується матеріал та композиційний склад, щзо гарантує певні фізико-механічні властивості готового продукту та має значно простішу та дешевшу технологію одержання матеріалу, щзо дезинфікує.

Ключові слова: біоцидні матеріали, цุелюлоза, базальтові волокна, глинисті мінерали.

\title{
ИСПОЛЬЗОВАНИЕ БАЗАЛЬТОВЫХ КОМПОЗИЦИЙ ПРИ ПОЛУЧЕНИИ БИОЦИДНОЙ БУМАГИ
}

\author{
В.М. Шевченко, Н.А. Гуц, А.Е. Шиак \\ Национальный технический университет Украины «Киевский политехнический \\ институт имени Игоря Сикорского», 03056, Киев, пр.Победы, 37, \\ (+38044)236-97-74,e-mail: gutsanelya@ukr.net
}

Использование электронных технологий несколько оттеснило бумагу, но не на столько, чтобы её забыли. Практически в любой отрасли народного хозяйства бумага всё ещё осталась наиболее используемой, постоянно необходимой, как в рабочих ситуациях, так и в домашнем быту. Проблема сохранения бумажных фондов - одна из насущных задач и сегодня. Известно, что старение бумаги - сложный процесс, на который влияют очень многие факторы (от вида и химического состава волокнистого материала веществ для проклеивания и окрашивания, $р$ н среды и т.п.).Условия сохранения бумаги (относительная влажность, температура воздушной среды, влияние лучей света и т.д.) - всё, что влияет на микробиологическое разрушение составляющчих бумаги.

Также особенное влияние химических вещуеств, которые применяются как носитель информации и реставраџии документов, и, которые не могут не влиять на бумажную основу.

В работе исследовались образиьь бумаги (конденсаторной, картонной для ламинирования, писчей) и применение к ним биоцидных материалов (Полидеза, Метатина, 
Гембара). Действие биочиидов проводили на тест-культурах микроскопических грибов, которые были изолированы из повреждённых документов.

Кроме того, параллельно исследовались образиы бумаги, которые образованы композиционным составом, содержащим базальтовое и целлюлозные волокна, монтмориллонитовую глину и гумат натрия (SH). Деформащчю образцов наблюдали по таким показателям: белизна материалов и прочность на излом (число двойных перегибов, ч.д.n.) - это свойство, на котором отражаются процессы старения бумаг.

В работе было показано, что образцы которые содержат в композиционном составе базальтовые и целлюлозные волокна, монтмориллонитовую глину и натриевые соли смоляных кислот (или гуматов натрия) в значительно большей степени угнетают распространение грибов и микроорганизмов, чем официально используемые государственные биоцидные материаль.

Поэтому в работе предлагают материал и композиционный состав, который гарантирует определённье физико-механические свойства готового продукта и имеет значительно простую дешёвую технологию получения дезинфицирующего биоцидного материала.

Ключевые слова: биоцидные материальl, изеллюлоза, базальтовые волокна, глинистые минеральл. 